\title{
Life table parameters of the pseudococcid predators Nephus includens and Nephus bisignatus (Coleoptera: Coccinelidae)
}

\author{
Dimitris C. KONTODimAS ${ }^{1}$, Panagiotis G. MiLONAS ${ }^{1 *}$, George J. STATHAS ${ }^{2}$, LeONidAs P. ECONOMOU ${ }^{3}$ \\ and NicKolas G. KAVALLIERATOS ${ }^{1}$
}

\author{
${ }^{1}$ Benaki Phytopathological Institute, Department of Entomology, St. Delta 8, 145 61, Kifissia, Greece, \\ ${ }^{2}$ Technological Educational Institute of Kalamata, 24 100, Antikalamos, Greece \\ ${ }^{3}$ Agricultural University of Athens, 75 Iera Odos str., 118 55, Votanikos, Athens, Greece
}

Key words. Coccinellidae, Nephus bisignatus, Nephus includens, development of immature stages, fecundity, survival, Planococcus citri, temperature

\begin{abstract}
The fecundity of the pseudococcid predators Nephus includens (Boheman) and N. bisignatus (Kirsch) (Coleoptera: Coccinellidae), fed on Planococcus citri Risso (Hemiptera: Pseudococcidae), was studied at several constant temperatures (15, 20, 25, 30, 32.5 and $35^{\circ} \mathrm{C}$ ). With additional data for the development of the immature stages, life-fecundity tables were constructed and some population parameters calculated. The average total fecundities of $N$. includens at the above temperatures were 49.2, 97.8, 162.8, 108.5, 87.4 and $31.1 \mathrm{eggs} / \mathrm{female}$, and average longevities 99.5, 84.7, 69.5, 61.1, 49.6 and 30.1 days, respectively. The net reproductive rates $\left(\mathrm{R}_{\mathrm{o}}\right)$ were 8.0, 32.2, 60.7, 32.6, 20.7 and 2.6 females/female, and the intrinsic rates of increase $\left(\mathrm{r}_{\mathrm{m}}\right) 0.014,0.041,0.083$, $0.086,0.077$ and 0.024 females/female/day, respectively. The average total fecundities of $N$. bisignatus at $15,20,25,30$ and $32.5 \mathrm{C}$ were 54.7, 72.1, 96.9, 56.0 and 22.8 eggs/female, and average longevities 116.1, 108.7, 71.8, 68.8 and 43.7 days, respectively. The net reproductive rates $\left(\mathrm{R}_{\mathrm{o}}\right)$ were 13.9, 26.4, 31.3, 15.2 and 3.6 females/female and the intrinsic rates of increase $\left(r_{\mathrm{m}}\right)$ were 0.017 , $0.035,0.060,0.051$ and 0.024 females/female/day, respectively. The survival of females at each temperature was fitted using a Weibull distribution $\left[S_{(t)}=e^{-\left(\frac{t}{b}\right)^{c}}\right.$ ]. Furthermore two mathematical models [Enkegaard equation: $F=(a+b+x) \cdot e^{(c+d \cdot x)}$, Analytis equation: $\left.F=a \cdot\left(x-x_{\min }\right)^{n} \cdot\left(x_{\min }-x\right)^{m}\right]$ were fitted to the fecundity data.
\end{abstract}

\section{INTRODUCTION}

Nephus bisignatus (Boheman) and N. includens (Kirsch) (Coleoptera: Coccinellidae) are important indigenous predators of mealybugs (Homoptera: Pseudococcidae) in Greece (Argyriou et al., 1976; Kontodimas, 1997). Nephus bisignatus is found in Northern Europe (South Norway, Finland, Sweden, Denmark, Netherlands and Germany) (Pope, 1973), but is also reported from Morocco, Southern France, Italy and Portugal (Pope, 1973; Francardi \& Covassi, 1992; Magro \& Hemptinne, 1999; Magro et al., 1999). It was recently reported in Greece on Thuja orientalis L. (Cupressaceae) and Pistacia lentiscus L. (Anacardiaceae) infested with Planococcus citri (Homoptera: Pseudococcidae) (Kontodimas, 1997). Nephus includens is reported from Greece, Turkey, Italy, Spain and Portugal (Bodenheimer, 1951; Viggiani, 1974; Argyriou et al., 1976; Longo \& Benfatto, 1987; Suzer et al., 1992; Katsoyannos, 1996; Magro \& Hemptinne, 1999; Magro et al., 1999). Although there are rare data on the fecundity of $N$. bisignatus or $N$. includens, Tranfaglia \& Viggiani (1972) report that females lay 150.6 eggs and live for 74 days at $25-27^{\circ} \mathrm{C}$ when fed on P. citri. The developmental zeros (lower temperature threshold) are estimated to be 10.9 and $9.4^{\circ} \mathrm{C}$ and thermal constants to be 490.5 and 614.30 degree-days for $N$. includens and $N$. bisignatus, respectively, using a linear model. The upper temperature thresholds are estimated to be 36.1 and $34.7^{\circ} \mathrm{C}$, respectively, using the Lactin non-linear model (Kontodimas et al., 2004). Life table parameters are often used by biological control workers (Messenger, 1964) when choosing the most effective biocontrol agents. In the absence of other criteria, the species with the greatest $r_{m}$ is usually selected.

In the present study the fecundities of the two predators were examined under laboratory conditions and used to obtain the following life table parameters: age specific survival and fecundity, reproductive value, expected remaining life time, net reproductive value, intrinsic rate of increase, mean generation time, finite rate of increase and doubling time. The above parameters can be used to estimate the rate of increase of a natural or released population (El Hag \& Zaitoon, 1996) and to determine when to release laboratory-reared coccinellid. In addition, two mathematical models were fitted to the fecundity data and the survival of adult females were described using the Weibull distribution. The current study compares the life table parameters of $N$. bisignatus and $N$. includens feeding on $P$. citri and provides useful information on their future use as biocontrol agents of mealybug pests.

\footnotetext{
* Corresponding author; e-mail: p.milonas@bpi.gr
} 
TABLE 1. Fecundity of Nephus includens and Nephus bisignatus at constant temperatures $\left(15,20,25,30,32.5\right.$ and $\left.35^{\circ} \mathrm{C}\right)$ (relative humidity: $65 \%$, photoperiod: 16L : 8D, prey: Planococcus citri).

\begin{tabular}{|c|c|c|c|c|c|c|c|c|c|c|c|}
\hline \multirow{2}{*}{\multicolumn{2}{|c|}{$\begin{array}{l}\text { Tempe- } \\
\text { rature } \\
\left({ }^{\circ} \mathrm{C}\right)\end{array}$}} & \multirow{2}{*}{$\begin{array}{c}\text { Females } \\
\text { (percentage) }\end{array}$} & \multirow{2}{*}{$\begin{array}{c}\text { Average total } \\
\text { fecundity } \\
\text { (eggs) }\end{array}$} & \multicolumn{3}{|c|}{ Survival of instars (\%) } & \multirow{2}{*}{$\begin{array}{c}\begin{array}{c}\text { Duration of } \\
\text { (egg-pupa) }\end{array} \\
\text { development (days) }\end{array}$} & \multirow{2}{*}{$\begin{array}{l}\text { Pre-ovipositional } \\
\text { period (days) }\end{array}$} & \multicolumn{3}{|c|}{ Longevity (days) } \\
\hline & & & & Egg & Larva & Pupa & & & Maximum & Average & Median \\
\hline \multirow{6}{*}{ 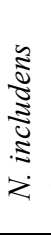 } & 15 & 67.5 & 49.2 & 75.0 & 50.0 & 92.6 & 94 & 20 & 174 & 99.5 & 93 \\
\hline & 20 & 62.0 & 97.8 & 86.8 & 84.8 & 92.6 & 46 & 9 & 128 & 84.7 & 85 \\
\hline & 25 & 55.5 & 162.8 & 94.3 & 78.8 & 96.2 & 30 & 6 & 94 & 69.5 & 73 \\
\hline & 30 & 58.5 & 108.5 & 90.0 & 77.8 & 89.3 & 21 & 4 & 91 & 61.1 & 68 \\
\hline & 32.5 & 59.5 & 87.4 & 87.0 & 67.5 & 92.6 & 19 & 4 & 77 & 49.6 & 53 \\
\hline & 35 & 63.5 & 31.1 & 69.4 & 36.5 & 78.9 & 21 & 4 & 52 & 30.1 & 29 \\
\hline \multirow{5}{*}{ 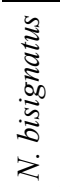 } & 15 & 64.0 & 54.68 & 77.8 & 48.1 & 96.2 & 91 & 22 & 193 & 116.1 & 107 \\
\hline & 20 & 60.0 & 72.12 & 82.9 & 79.4 & 92.6 & 48 & 10 & 159 & 108.7 & 113 \\
\hline & 25 & 53.0 & 96.88 & 90.2 & 73.0 & 92.6 & 32 & 7 & 110 & 71.8 & 76 \\
\hline & 30 & 57.5 & 56.00 & 83.0 & 65.9 & 86.2 & 25 & 5 & 98 & 68.8 & 73 \\
\hline & 32.5 & 60.5 & 22.80 & 73.7 & 42.9 & 83.3 & 28 & 6 & 74 & 43.7 & 46 \\
\hline
\end{tabular}

N. includens
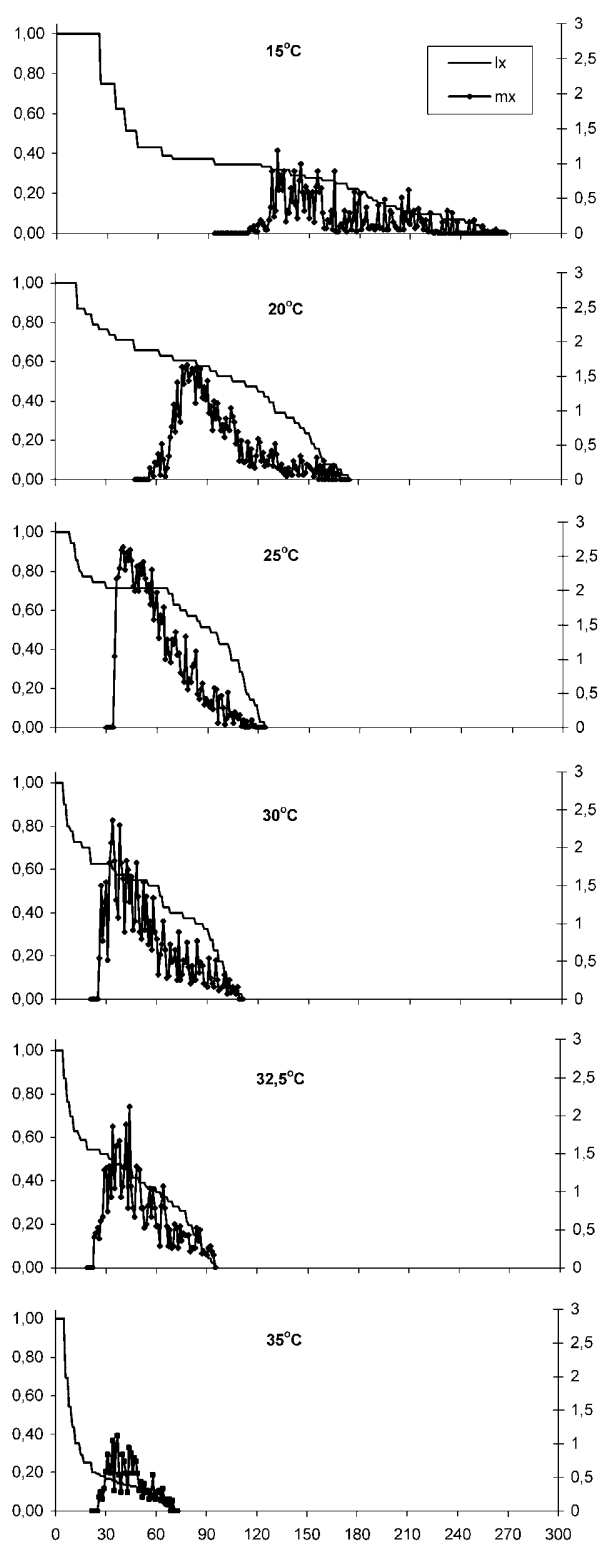

N. bisignatus
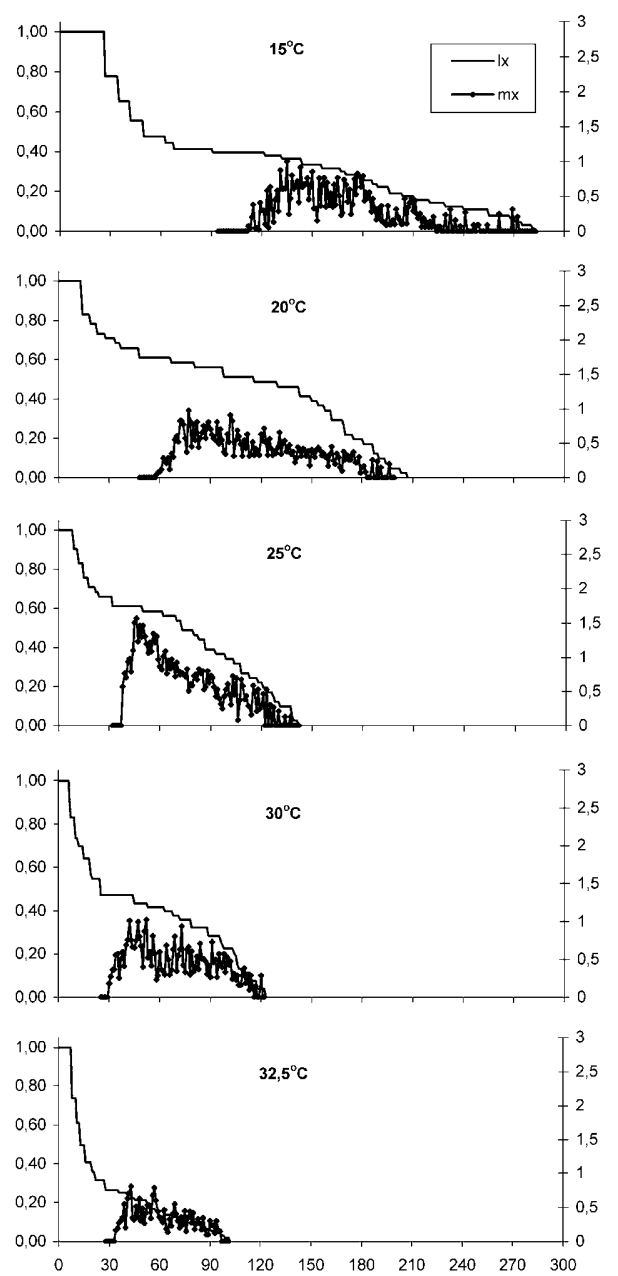

Fig. 1. Age specific survival $\left(l_{x}\right)$ and age specific fecundity $\left(m_{x}\right)$ of Nephus includens and Nephus bisignatus at different constant temperatures. 

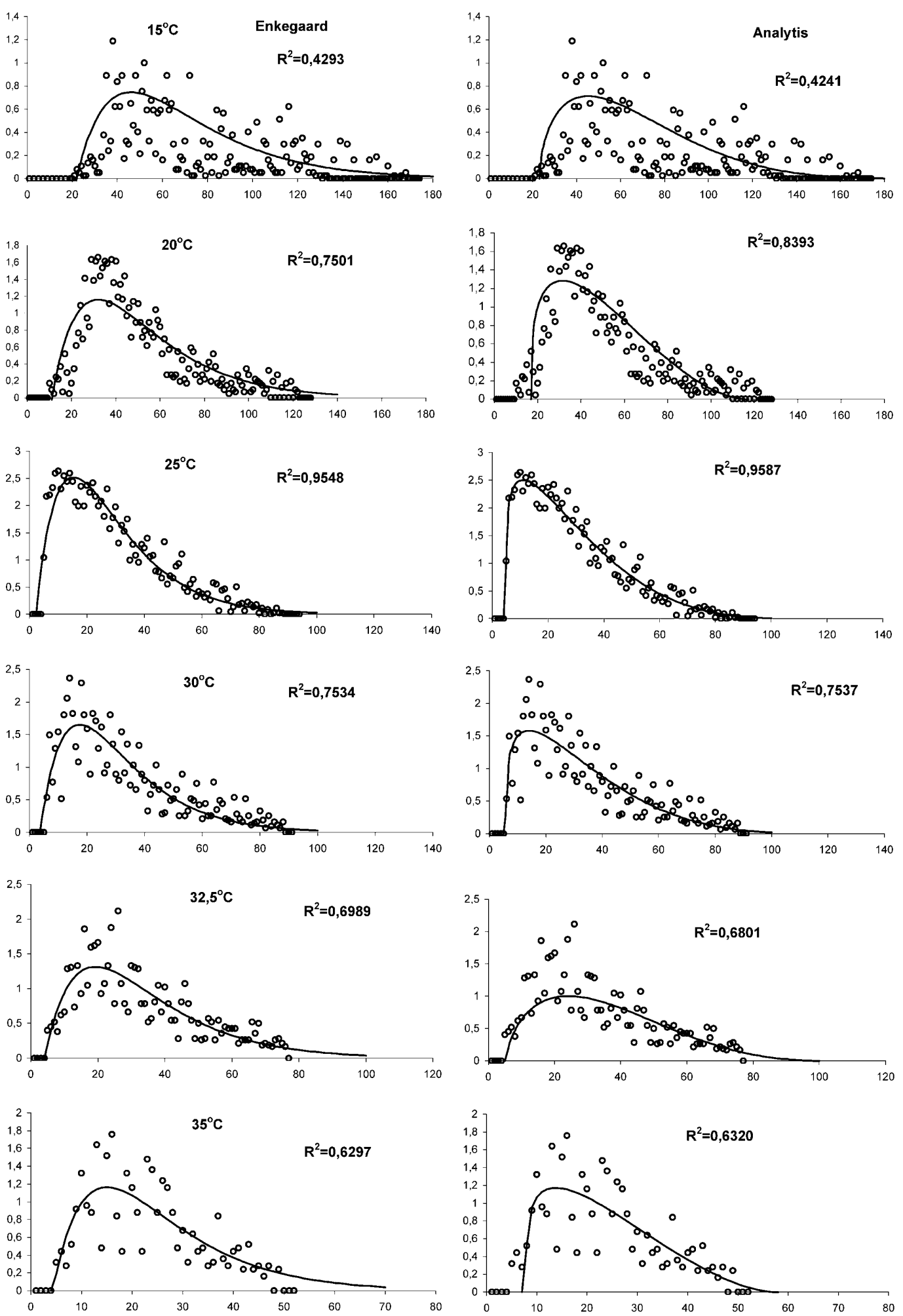

Fig. 2. The age specific fecundity $\left(m_{x}\right)$ of Nephus includens at different constant temperatures fitted using Enkegaard and Analytis models.

\section{MATERIAL AND METHODS}

\section{Rearing methods and experimental conditions}

Nephus bisignatus and $N$. includens were originally collected in 1997 from Thuja orientalis L. (Cupressaceae) in Attiki County (Central Greece) and Citrus sp. (Rutaceae) in Preveza County (Northwestern Greece), respectively, both infested with
P. citri. The same mealybug was used as prey for rearing these predators in the laboratory. Citrus mealybug was reared on potato sprouts (Solanum tuberosum) and pumpkins (Cucurbita pepo and $C$. maxima) at $25 \pm 1{ }^{\circ} \mathrm{C}, 16 \mathrm{~L}: 8 \mathrm{D}$ photoperiod and 65 $\pm 2 \% \mathrm{RH}$, in large plastic boxes $(30 \times 40 \times 15 \mathrm{~cm})$ tightly covered with mesh (holes: $0.3 \times 0.4 \mathrm{~cm}$ ). Both predators were reared in large cylindrical Plexiglas cages $(50 \mathrm{~cm}$ height $\times 30$ 

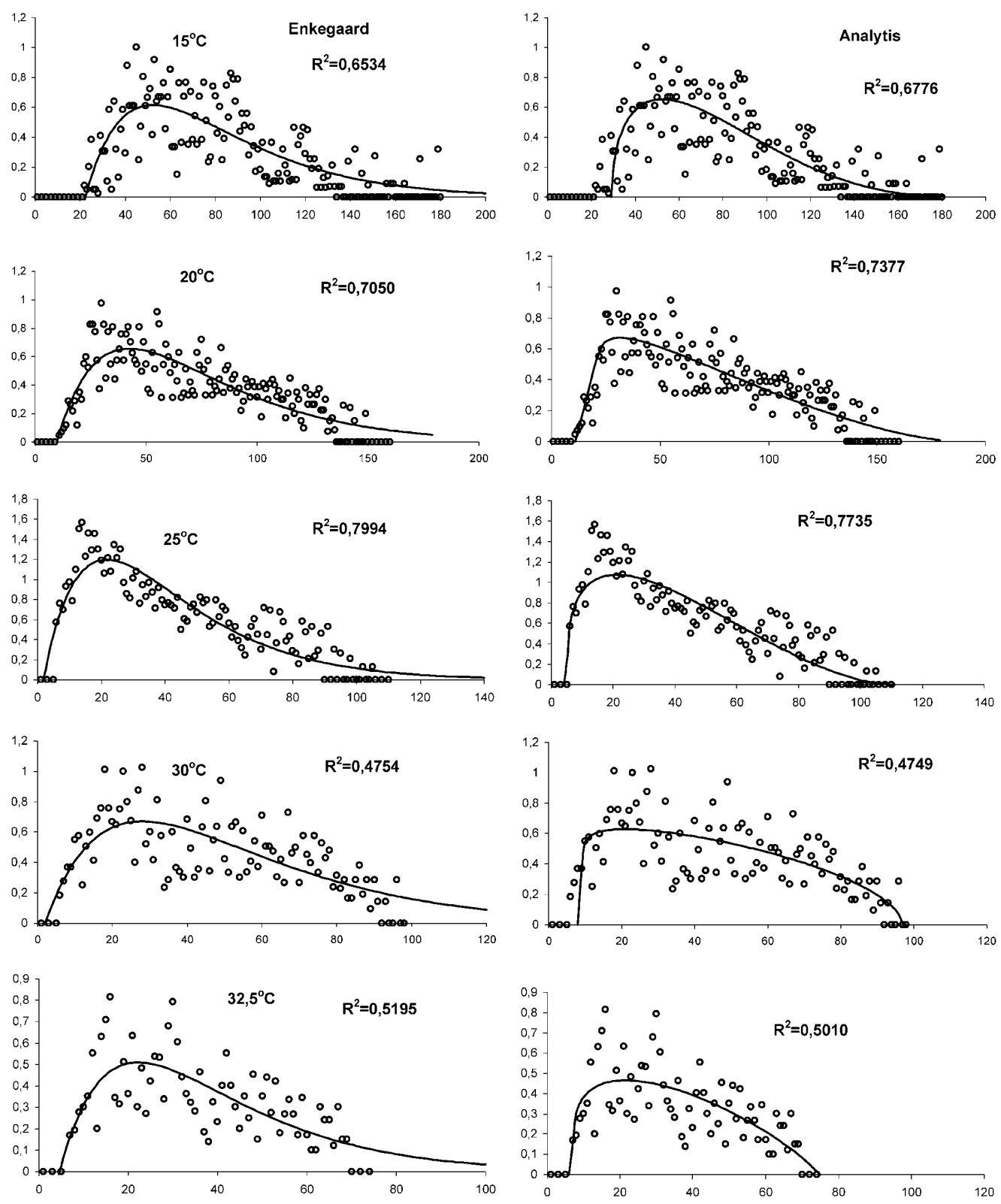

Fig. 3. The age specific fecundity $\left(m_{x}\right)$ of Nephus bisignatus at different constant temperatures fitted using Enkegaard and Analytis models.

$\mathrm{cm}$ diameter) containing an abundance of prey under the following controlled conditions: $15,20,25,30,32.5$, or $35 \pm 1{ }^{\circ} \mathrm{C}$; $65 \pm 2 \% \mathrm{RH} ; 16 \mathrm{~L}: 8 \mathrm{D}$.

The fecundity of the two predators was determined using 25 newly emerged pairs of adults of each species, which were kept in plastic cages under constant conditions (temperature: $15 \pm 1$, $20 \pm 1,25 \pm 1,30 \pm 1,32,5 \pm 1,35 \pm 1^{\circ} \mathrm{C}$, relative humidity: 65 $\pm 2 \%$ and an abundant supply of Planococcus citri as food). The same conditions were used to study the survival of the immature stages and the sex ratio of the progeny. These experiments were done in the spring of 2001 .

The longevity and fecundity of the 25 females were recorded daily and the following table parameters calculated (Birch, 1948; Southwood, 1966; Izhevsky \& Orlinsky, 1988; Carey, 1993; Liu et al., 1997; Lysyk, 2001):

Age specific survival $\left(l_{x}\right)$ of 25 females.
Age specific fecundity $\left(m_{x}\right)$ (= females born/female) by multiplying the mean number of eggs by the ratio $(q / q+\hat{o})($ Liu et al, 1997).

Net reproductive value: $R_{0}=\Sigma\left(l_{x} \cdot m_{x}\right)$, the average number of offspring a female in a population will produce in her lifetime.

Intrinsic rate of increase $\left(r_{m}\right)$ from the solution of the Euler equation, $\Sigma\left(e^{r_{m} \cdot x} \cdot l_{x} \cdot m_{x}\right)=1$.

Mean generation time using two different formulas: $T_{c}=\frac{\sum\left(x \cdot l_{x} \cdot m_{x}\right)}{R_{0}}$ and $T=\frac{\ln R_{0}}{r_{m}}$.

Finite rate of increase: $\lambda=e^{r_{m}}$, the number of times the population increases per unit time.

Doubling time: $D T=\frac{\ln 2}{r_{m}}$, the time it takes a population to double in size.

Reproductive value of the females: $V_{x}=\frac{\sum_{y=1}\left(e^{r m \cdot y} \cdot l_{y} \cdot m_{y}\right)}{l_{x} \cdot e^{r} \cdot x}$

Expected remaining life time of the females: $E_{x}=\frac{\sum_{i=x} \frac{l_{y+l_{y+1}}}{2}}{l_{x}}$.

The fecundity was calculated as females/female. 
TABLE 2. Values of the parameters of the Analytis and Enkegaard models fitted to the data for Nephus includens and Nephus bisignatus.

\begin{tabular}{|c|c|c|c|c|c|c|c|}
\hline & Parameter & $15^{\circ} \mathrm{C}$ & $20^{\circ} \mathrm{C}$ & $25^{\circ} \mathrm{C}$ & $30^{\circ} \mathrm{C}$ & $32.5^{\circ} \mathrm{C}$ & $35^{\circ} \mathrm{C}$ \\
\hline \multirow{7}{*}{$\begin{array}{c}\text { Enkegaard equation } \\
F=(a+b+x) \cdot e^{(c+d \cdot x)}\end{array}$} & \multicolumn{7}{|c|}{ Nephus includens } \\
\hline & $a$ & -1.4494 & -0.8606 & -0.4189 & -0.1422 & -0.0490 & -0.0544 \\
\hline & $b$ & 0.0665 & 0.0771 & 0.1846 & 0.0387 & 0.0118 & 0.0125 \\
\hline & $c$ & -1.1245 & -1.2111 & -1.2156 & -2.3972 & -3.2682 & -3.5749 \\
\hline & $d$ & 0.0411 & 0.0480 & 0.0764 & 0.0726 & 0.0661 & 0.0938 \\
\hline & $\mathrm{R}^{2}$ & 0.4293 & 0.7501 & 0.9548 & 0.7534 & 0.6989 & 0.6297 \\
\hline & RSS & 5.7820 & 7.2077 & 5.2818 & 7.6727 & 4.9999 & 3.9593 \\
\hline \multirow{7}{*}{$\begin{array}{c}\text { Analytis equation } \\
F=a \cdot\left(x-x_{\min }\right)^{n} \cdot\left(x_{\min }-x\right)^{m}\end{array}$} & $p$ & $0.1943 \times 10^{-10}$ & $0.1564 \times 10^{-3}$ & $0.4203 \times 10^{-6}$ & $0.1662 \times 10^{-7}$ & $0.9668 \times 10^{-6}$ & $0.1427 \times 10^{-2}$ \\
\hline & $x_{\min }$ & 23.0013 & 17.0021 & 4.9757 & 5.9522 & 5.3796 & 7.9372 \\
\hline & $x_{\max }$ & 213.0101 & 117.1020 & 113.5814 & 129.3580 & 104.7326 & 57.2146 \\
\hline & $m$ & 0.5802 & 0.3101 & 0.1923 & 0.2604 & 0.6388 & 0.2246 \\
\hline & $n$ & 4.3973 & 1.8400 & 3.2941 & 3.7543 & 2.7292 & 1.6743 \\
\hline & $\mathrm{R}^{2}$ & 0.4241 & 0.8393 & 0.9587 & 0.7536 & 0.6809 & 0.6320 \\
\hline & RSS & 5.6799 & 3.2129 & 2.8179 & 7.4036 & 5.1083 & 3.6718 \\
\hline \multirow{7}{*}{$\begin{array}{c}\text { Enkegaard equation } \\
F=(a+b+x) \cdot e^{(c+d \cdot x)}\end{array}$} & \multicolumn{7}{|c|}{ Nephus bisignatus } \\
\hline & $a$ & -3.9781 & -0.4657 & -0.0653 & -0.1173 & -0.0683 & \\
\hline & $b$ & 0.1780 & 0.0475 & 0.0355 & 0.0578 & 0.0147 & \\
\hline & $c$ & 0.4192 & -0.4376 & -1.6212 & -0.2671 & -1.9440 & \\
\hline & $d$ & 0.0333 & 0.0306 & 0.0504 & 0.0383 & 0.0568 & \\
\hline & $\mathrm{R}^{2}$ & 0.6534 & 0.7050 & 0.79939 & 0.4754 & 0.5195 & \\
\hline & RSS & 4.3339 & 2.5592 & 3.6085 & 2.8634 & 1.2330 & \\
\hline \multirow{7}{*}{$\begin{array}{c}\text { Analytis equation } \\
F=a \cdot\left(x-x_{\min }\right)^{n} \cdot\left(x_{\min }-x\right)^{m}\end{array}$} & $p$ & $1.8740 \times 10^{-7}$ & $1.3201 \times 10^{-4}$ & $2.0744 \times 10^{-4}$ & 0.0448 & 0.0089 & \\
\hline & $x_{\min }$ & 29.4975 & 21.0000 & 4.9452 & 8.9900 & 6.9457 & \\
\hline & $x_{\max }$ & 193.9480 & 189.2699 & 110.0528 & 97.0369 & 74.5461 & \\
\hline & $m$ & 0.4456 & 0.1079 & 0.3126 & 0.0875 & 0.2311 & \\
\hline & $n$ & 2.7602 & 1.6363 & 1.7119 & 0.5595 & 0.8399 & \\
\hline & $\mathrm{R}^{2}$ & 0.6776 & 0.7377 & 0.7735 & 0.4749 & 0.5010 & \\
\hline & RSS & 3.8887 & 2.0879 & 4.8254 & 2.4862 & 1.1778 & \\
\hline
\end{tabular}

Two mathematical models were used to fit the data on fecundity:

1. The Enkegaard equation: $F=(a+b \cdot x) \cdot e^{-(c+d \cdot x)}$ (Enkegaard, 1993),

2. The Analytis equation: $F=q \cdot\left(x-x_{\min }\right)^{n} \cdot\left(x_{\min }-x\right)^{m}$ (Analytis, 1974, 1977, 1980; Kontodimas et al., 2004), where $F$ is the fecundity, $x$ are the days after emergence, $a, b, c, d, q, x_{\min }, x_{\max }$, $n, m$ : parameters and $e=2.178$.

The Weibull frequency distribution was used to describe the age specific survival of female adults. The probability that an individual lives at least to time $t$ was calculated following Deevey (1947), Pinder et al. (1978), Tingle \& Copland (1989) and Wang et al. (2000): $S_{(t)}=e^{\left(\frac{t}{b}\right)^{c}}$, for $t>0$ where $b$ is a scale parameter that is inversely related to the mortality rate (ie, larger $b$ value indicates slower decline of the population) and $c$ is a shape parameter that allows the model to produce survival distributions of different forms, from exponential to an extreme inverted S shape. Values of the shape parameter $c>1, c=1$ or $c$ $<1$ correspond to Deevey's (1947) type I, II or III survivorship curves, respectively (Pinder et al., 1978).

Estimates of the models' parameters and coefficients of nonlinear regression $\left(\mathrm{R}^{2}\right)$ were obtained with statistical packages JMP v.4.0.2 (SAS, 1989) and SPSS v.9.0.0 (SPSS, 1999).

\section{RESULTS AND DISCUSSION}

Both species were most fecund at $25^{\circ} \mathrm{C}(162.8$ eggs/female in $N$. includens, 96.9 eggs/female in $N$. bisignatus). $N$. includens had a consistently higher fecundity than $N$. bisignatus at each experimental temperature, except $15^{\circ} \mathrm{C}$ (Table 1). However for both species, the highest fecundity was smaller than that reported for $C$. montrouzieri (Babu \& Azam, 1988) and N. reunioni (Izhevsky \& Orlinsky, 1988) but higher than that reported by Persad \& Khan (2002) for C. montrouzieri and Scymnus coccivora. Longevity of each species was different at each experimental temperature. Average longevity of $N$. includens was shorter than that of $N$. bisignatus at each temperature, except $32.5^{\circ} \mathrm{C}$. It seems that although $N$. bisignatus had a longer lifespan, its reproductive activity was shorter than that of $N$. includens. However both species oviposited $60 \%$ of their eggs within the first $40 \%$ of their adult lifetime. The age specific survival $\left(l_{x}\right)$ and age specific fecundity $\left(m_{x}\right)$ of the two predators are presented in Fig. 1. The description of the age specific fecundity $\left(m_{x}\right)$ by Enkegaard and Analytis models is presented in Figs 2 and 3 and the values of 

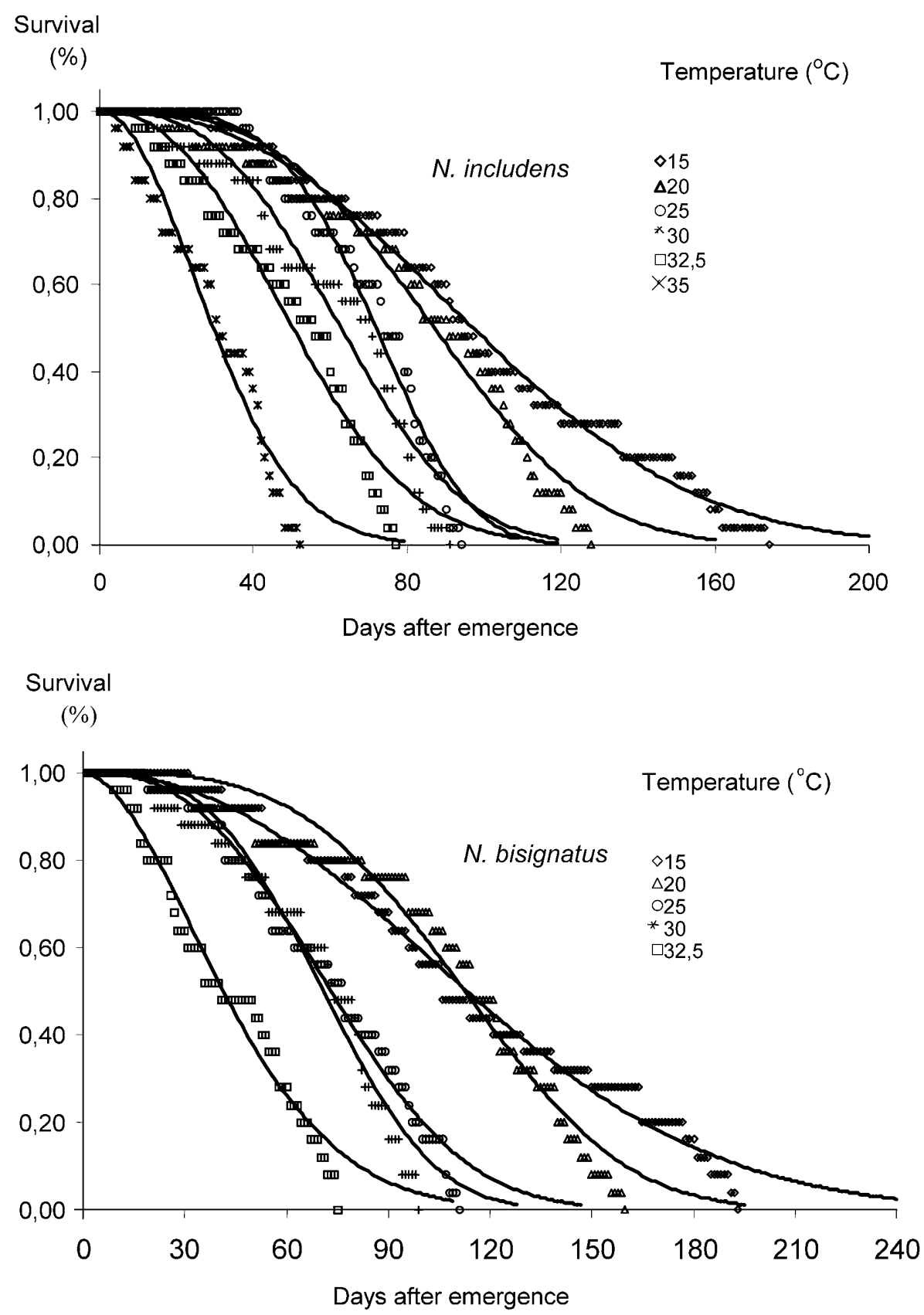

Fig. 4 . Survival of Nephus includens and Nephus bisignatus at different constant temperatures fitted using the Weibull function.

TABLE 3. Values of the Weibull parameters $S_{(t)}=e^{-\left(\frac{t}{b}\right)^{c}}$.

\begin{tabular}{lccccccc}
\hline & Parameter & $15^{\circ} \mathrm{C}$ & $20^{\circ} \mathrm{C}$ & $25^{\circ} \mathrm{C}$ & $30^{\circ} \mathrm{C}$ & $32.5^{\circ} \mathrm{C}$ & $35^{\circ} \mathrm{C}$ \\
\hline \multirow{4}{*}{ N. includens } & $\mathrm{b}$ & 112.9614 & 98.0543 & 78.4127 & 71.2303 & 58.7081 & 35.5751 \\
& $\mathrm{c}$ & 2.4175 & 3.0638 & 4.1966 & 2.8617 & 2.3469 & 1.9733 \\
& $\mathrm{R}^{2}$ & 0.9929 & 0.9772 & 0.9771 & 0.9532 & 0.9628 & 0.9556 \\
& $\mathrm{RSS}$ & 0.1382 & 0.2716 & 0.1923 & 0.3820 & 0.2427 & 0.2111 \\
\hline \multirow{5}{*}{ N. bisignatus } & $\mathrm{b}$ & 133.5318 & 125.4435 & 83.7265 & 79.5416 & 50.9824 & 133.5318 \\
& $\mathrm{c}$ & 2.2264 & 3.4027 & 2.6717 & 3.1422 & 1.7921 & 2.2264 \\
& $\mathrm{R}$ & 0.9917 & 0.9722 & 0.9890 & 0.9698 & 0.9776 & 0.9917 \\
& $\mathrm{RSS}$ & 0.1539 & 0.4003 & 0.1132 & 0.2522 & 0.1445 & 0.1539 \\
\hline
\end{tabular}


TABLE 4. Summaries of the life tables of Nephus includens at different constant temperatures $(15,20,25,30,32.5$ and $35 \pm$ $1{ }^{\circ} \mathrm{C}$ ), relative humidity: $65 \pm 2 \%$ and photoperiod $16 \mathrm{~L}: 8 \mathrm{D}$, when fed on Planococcus citri.

\begin{tabular}{|c|c|c|c|c|}
\hline Day & $\begin{array}{l}\text { Age specific } \\
\text { survival }\left(1_{x}\right)\end{array}$ & $\begin{array}{l}\text { Age specific fecundity } \\
\text { (sum of days before) } \\
\left(\mathrm{m}_{\mathrm{x}}\right)(\text { females/female })\end{array}$ & $\begin{array}{c}\text { Reproductive } \\
\text { value }\left(\mathrm{V}_{\mathrm{x}}\right) \\
\text { (females/female) }\end{array}$ & $\begin{array}{c}\text { Expected } \\
\text { remaining life } \\
\text { time }\left(E_{x}\right)(\text { days })\end{array}$ \\
\hline \multicolumn{5}{|c|}{$15^{\circ} \mathrm{C}$} \\
\hline 12 & 0.35 & 0.5 & 15.0 & 72.0 \\
\hline 15 & 0.28 & 14.3 & 9.4 & 56.4 \\
\hline 18 & 0.21 & 9.3 & 4.4 & 38.6 \\
\hline 21 & 0.11 & 5.4 & 2.6 & 31.5 \\
\hline 24 & 0.07 & 32 & 0.3 & 12.5 \\
\hline 26 & 0.01 & 0.6 & 0.0 & 1.0 \\
\hline \multicolumn{5}{|c|}{$20^{\circ} \mathrm{C}$} \\
\hline 60 & 0.66 & 0.8 & 17.3 & 70.2 \\
\hline 80 & 0.61 & 17.5 & 20.3 & 55.8 \\
\hline 10 & 0.53 & 23.0 & 9.4 & 42.7 \\
\hline 12 & 0.45 & 10.6 & 4.3 & 28.1 \\
\hline 14 & 0.32 & 5.0 & 1.8 & 16.0 \\
\hline 16 & 0.08 & 3.2 & 0.5 & 9.8 \\
\hline 17 & 0.03 & 0.7 & 0.0 & 1.0 \\
\hline \multicolumn{5}{|c|}{$25^{\circ} \mathrm{C}$} \\
\hline 30 & 0.71 & 0.0 & 17.0 & 61.6 \\
\hline 45 & 0.71 & 25.3 & 23.1 & 46.6 \\
\hline 60 & 0.71 & 31.1 & 13.7 & 31.6 \\
\hline 75 & 0.60 & 18.2 & 7.1 & 20.8 \\
\hline 90 & 0.51 & 10.1 & 2.9 & 20.0 \\
\hline 10 & 0.34 & 4.5 & 0.7 & 10.3 \\
\hline 12 & 0.06 & 1.1 & 0.0 & 2.5 \\
\hline \multicolumn{5}{|c|}{$30^{\circ} \mathrm{C}$} \\
\hline 30 & 0.63 & 5.6 & 16.2 & 50.6 \\
\hline 45 & 0.58 & 24.0 & 11.2 & 40.5 \\
\hline 60 & 0.53 & 16.0 & 5.2 & 27.9 \\
\hline 75 & 0.40 & 8.0 & 3.8 & 21.2 \\
\hline 90 & 0.33 & 6.0 & 1.6 & 9.1 \\
\hline 10 & 0.05 & 3.5 & 0.3 & 4.0 \\
\hline \multicolumn{5}{|c|}{$32.5^{\circ} \mathrm{C}$} \\
\hline 26 & 0.54 & 1.8 & 12.1 & 41.9 \\
\hline 39 & 0.48 & 15.6 & 11.6 & 33.8 \\
\hline 52 & 0.39 & 15.2 & 7.0 & 26.0 \\
\hline 65 & 0.33 & 9.5 & 4.1 & 16.9 \\
\hline 78 & 0.22 & 5.5 & 2.1 & 8.8 \\
\hline 91 & 0.04 & 3.8 & 0.7 & 2.5 \\
\hline \multicolumn{5}{|c|}{$35^{\circ} \mathrm{C}$} \\
\hline 30 & 0.17 & 1.6 & 10.9 & 25.0 \\
\hline 40 & 0.14 & 7.1 & 7.5 & 18.7 \\
\hline 50 & 0.12 & 2.8 & 6.3 & 11.8 \\
\hline 60 & 0.08 & 2.9 & 1.1 & 5.3 \\
\hline 70 & 0.01 & 1.8 & 0.2 & 2.5 \\
\hline
\end{tabular}

Enkegaard and Analytis parameters in Table 2. Both models gave a satisfactory fit at 20,25 and $30^{\circ} \mathrm{C}$ for $N$. includens and 20 and $25^{\circ} \mathrm{C}$ for $N$. bisignatus, respectively, for which the data were less variable than at the other temperatures. The coefficient of nonlinear regression $\left(R^{2}\right)$ and the residual sum of squares (RSS) were used as criteria of goodness of fit. The higher the $R^{2}$ and lower the RSS the better the fit (Kontodimas et al., 2004).

The description of the age specific survival of female adults $\left(l_{x}\right)$ using the Weibull frequency distribution is pre-
TABLE 5. Summaries of the life tables of Nephus bisignatus at different constant temperatures $(15,20,25,30,32.5$ and $35 \pm$ $1{ }^{\circ} \mathrm{C}$ ), relative humidity: $65 \pm 2 \%$ and photoperiod $16 \mathrm{~L}: 8 \mathrm{D}$, when fed on Planococcus citri.

\begin{tabular}{|c|c|c|c|c|}
\hline Day & $\begin{array}{l}\text { Age specific } \\
\text { survival }\left(1_{x}\right)\end{array}$ & $\begin{array}{l}\text { Age specific fecundity } \\
\text { (sum of days before) } \\
\left(\mathrm{m}_{\mathrm{x}}\right) \text { (females/female) }\end{array}$ & $\begin{array}{c}\text { Reproductive } \\
\text { value }\left(\mathrm{V}_{\mathrm{x}}\right) \\
\text { (females/female) }\end{array}$ & $\begin{array}{c}\text { Expected } \\
\text { remaining life } \\
\text { time }\left(E_{\mathrm{x}}\right)(\text { days })\end{array}$ \\
\hline \multicolumn{5}{|c|}{$15^{\circ} \mathrm{C}$} \\
\hline$\overline{120}$ & 0.40 & 1.6 & 18.8 & 85.6 \\
\hline 150 & 0.33 & 16.8 & 15.0 & 69.0 \\
\hline 180 & 0.27 & 16.0 & 7.2 & 52.8 \\
\hline 210 & 0.17 & 8.4 & 2.9 & 45.0 \\
\hline 240 & 0.11 & 3.1 & 0.9 & 29.2 \\
\hline 270 & 0.06 & 1.2 & 0.2 & 8.0 \\
\hline \multicolumn{5}{|c|}{$20^{\circ} \mathrm{C}$} \\
\hline 60 & 0.61 & 0.2 & 12.9 & 84.4 \\
\hline 80 & 0.59 & 10.0 & 14.2 & 69.1 \\
\hline 100 & 0.51 & 12.3 & 12.2 & 55.6 \\
\hline 120 & 0.49 & 10.0 & 9.5 & 37.6 \\
\hline 140 & 0.46 & 8.9 & 5.7 & 22.0 \\
\hline 160 & 0.34 & 6.9 & 3.3 & 27.6 \\
\hline 180 & 0.20 & 5.3 & 0.8 & 10.8 \\
\hline 200 & 0.05 & 1.1 & 0.0 & 3.8 \\
\hline \multicolumn{5}{|c|}{$25^{\circ} \mathrm{C}$} \\
\hline$\overline{45}$ & 0.61 & 17.4 & 7.3 & 58.34 \\
\hline 60 & 0.59 & 11.3 & 18.6 & 45.6 \\
\hline 75 & 0.49 & 8.5 & 12.7 & 37.9 \\
\hline 90 & 0.39 & 6.1 & 10.3 & 30.2 \\
\hline 105 & 0.32 & 4.0 & 7.3 & 20.3 \\
\hline 120 & 0.22 & 1.5 & 5.6 & 12.2 \\
\hline 135 & 0.10 & 0.1 & 1.9 & 3.8 \\
\hline \multicolumn{5}{|c|}{$30^{\circ} \mathrm{C}$} \\
\hline 30 & 0.47 & 9.8 & 0.2 & 61.1 \\
\hline 45 & 0.43 & 10.5 & 8.4 & 50.2 \\
\hline 60 & 0.42 & 7.7 & 9.6 & 37.1 \\
\hline 75 & 0.36 & 6.5 & 7.5 & 26.8 \\
\hline 90 & 0.28 & 4.8 & 7.1 & 16.7 \\
\hline 105 & 0.19 & 1.4 & 6.5 & 7.4 \\
\hline \multicolumn{5}{|c|}{$32.5^{\circ} \mathrm{C}$} \\
\hline 39 & 0.25 & 8.9 & 1.9 & 32.4 \\
\hline 52 & 0.21 & 6.6 & 6.0 & 26.4 \\
\hline 65 & 0.14 & 5.1 & 5.7 & 23.1 \\
\hline 78 & 0.12 & 2.8 & 4.4 & 12.9 \\
\hline 91 & 0.05 & 1.0 & 3.2 & 7.3 \\
\hline
\end{tabular}

sented in Fig. 4 and the values of the Weibull parameters in Table 3. In both species it is a type I survival curve, as parameter $c$ is $>1$ (Tingle \& Copland, 1989; Wang et al., 2000). Using mathematical models to describe the reproductive capacity and survival enables one to compare data with similar average values, which differ in their temporal distribution (Tingle \& Copland, 1989).

The fact that both species showed an increase in the sex ratio favouring females at temperatures close to their lower and upper thresholds (Kontodimas et al., 2004) is an important advantage of the survival of the species at these temperatures. Summaries of the life tables for each species and temperature are presented in Tables 4 and 5, and the life table parameters calculated for each species in Table 6. Differences between the species in the adaptation to temperature are indicated by their intrinsic rates of natural increase $\left(r_{m}\right)$. As expected, life table parameters were sensitive to temperature in both species. Neverthe- 
TABLE 6. Life table parameters of Nephus includens and Nephus bisignatus.

\begin{tabular}{|c|c|c|c|c|c|c|}
\hline $\begin{array}{l}\text { Tempera- } \\
\text { ture }\left({ }^{\circ} \mathrm{C}\right)\end{array}$ & $\begin{array}{l}\text { Net reproductive value } \\
\qquad R_{0}=\Sigma\left(l_{x} \cdot m_{x}\right)\end{array}$ & $\begin{array}{l}\text { Intrinsic rate of increase }\left(r_{m}\right) \\
\qquad \sum\left(e^{r_{m} \cdot x} \cdot l_{x} \cdot m_{x}\right)=1\end{array}$ & $\begin{array}{l}\text { Mean generation time } \\
\qquad T_{c}=\frac{\sum\left(x \cdot x_{x} \cdot m_{x}\right)}{R_{0}}\end{array}$ & $T=\frac{\ln R_{0}}{r_{m}}$ & $\begin{array}{l}\text { Doubling time } \\
\qquad D T=\frac{\ln 2}{r_{m}}\end{array}$ & $\begin{array}{c}\text { Finite rate of } \\
\text { increase } \lambda=e^{r_{m}}\end{array}$ \\
\hline \multicolumn{7}{|c|}{ N. includens } \\
\hline 15 & 8.0 & 0.014 & 153.1 & 149.3 & 49.7 & 1.01 \\
\hline 20 & 32.2 & 0.041 & 90.3 & 84.6 & 16.9 & 1.04 \\
\hline 25 & 60.7 & 0.083 & 56.4 & 49.4 & 8.3 & 1.09 \\
\hline 30 & 32.6 & 0.086 & 47.9 & 40.4 & 8.0 & 1.09 \\
\hline 32.5 & 20.7 & 0.077 & 45.1 & 39.0 & 9.0 & 1.08 \\
\hline 35 & 2.6 & 0.024 & 40.6 & 39.7 & 29.3 & 1.02 \\
\hline \multicolumn{7}{|c|}{ N. bisignatus } \\
\hline 15 & 13.9 & 0.017 & 157.2 & 151.8 & 40.0 & 1.017 \\
\hline 20 & 26.4 & 0.035 & 106.8 & 94.7 & 20.07 & 1.035 \\
\hline 25 & 31.3 & 0.060 & 66.0 & 57.1 & 11.49 & 1.062 \\
\hline 30 & 15.2 & 0.051 & 62.0 & 53.3 & 13.58 & 1.052 \\
\hline 32.5 & 3.6 & 0.024 & 55.0 & 52.7 & 28.31 & 1.025 \\
\hline
\end{tabular}

less, $N$. includens performed better than $N$. bisignatus in almost all cases except $15^{\circ} \mathrm{C}$. The highest net reproductive rate $\left(R_{0}\right)$ was recorded at $25^{\circ} \mathrm{C}$ in $N$. includens $(60.7$ females/female) and the highest intrinsic rate of increase $\left(r_{m}\right)$ at $30^{\circ} \mathrm{C}$. The respective values in $N$. bisignatus were recorded at $25^{\circ} \mathrm{C}$. The higher value of $\left(r_{m}\right)$ for $N$. includens at temperatures between $25-32.5^{\circ} \mathrm{C}$ is due to the greater survival of immature stages, which indirectly influence net reproductive rate $\left(R_{0}\right)$ (Persad \& Khan 2002). Reproductive value $\left(\mathrm{V}_{\mathrm{x}}\right)$ for both species was highest at $25^{\circ} \mathrm{C}$, with seven day old females of $N$. includens having an expected remaining life time $\left(\mathrm{E}_{\mathrm{x}}\right)$ of 55 days, and twelve day old females of $N$. bisignatus an expected remaining life time $\left(\mathrm{E}_{\mathrm{x}}\right)$ of 59 days. However, in $N$. includens the reproductive value $\left(\mathrm{V}_{\mathrm{x}}\right)$ remained at a high level ( $>15$ females/female) until the $25^{\text {th }}$ day of their life and $20^{\text {th }}$ day in $N$. bisignatus. Life history parameters need to be determined in the laboratory, which usually involved rearing them under constant conditions, despite the fact that insects are subjected to more complex and fluctuating conditions in their natural environment. Nevertheless, life tables remain a very useful tool for evaluating the effectiveness of natural enemies for controlling pests under various climatic conditions and in different habitats (Birch 1948, Jervis \& Copland 1996). The parameter $r_{m}$ is of especial interest because it integrates the effects of mortality and fertility in a single value.

In inundative releases of a biological control agent, its reproductive value $\left(\mathrm{V}_{\mathrm{x}}\right)$ and expected remaining life time $\left(E_{x}\right)$ are important. Probably the best time to release an agent is at its maximum reproductive value. Our results show that this occurs in early summer in central Greece. On the other hand, a release at the end of summer should consider whether the expected remaining life time $\left(\mathrm{E}_{\mathrm{x}}\right)$ of the natural enemy is sufficiently long for it to become established over winter. Maximum value of $V x$ also was recorded for newly emerged adults or 15 day old adults. The biological meaning of this result is that these individuals will produce more progeny in the next generation than their co-specifics of other age classes. Thus, it is concluded that newly emerged adults are the ideal individuals for release.
A comparison of the population parameters $\left(R_{0,}, r_{m}, T_{c}\right.$, $D T$ ) indicates that $N$. includens is capable of developing high populations in temperatures ranging between $20-32.5^{\circ} \mathrm{C}$. Temperatures $15-20^{\circ} \mathrm{C}$ are considered to be more suitable for "storage" of $N$. includens, based on the reproductive value $\left(\mathrm{V}_{\mathrm{x}}\right)$ and expected remaining life time $\left(E_{x}\right)$. The results of the current study provide information that will help facilitate the more effective control of mealybug pests by these coccinellid predators. The above results, in combination with data on development at constant temperatures and on their predatory activity (Kontodimas, 2004; Kontodimas et al., 2004), shows that $N$. includens could be an effective predator of $P$. citri, at least, in warm, southern temperate regions.

\section{REFERENCES}

AnAlytis S. 1974: Der Einsatz von Wachstumsfunktionen zur Analyse der Befallskurven von Pflanzenkrankheiten. Phytopathol. Z. 81: 133-144.

ANALYTIS S. 1977: Über die Relation zwischen biologischer Entwicklung und Temperatur bei phytopathogenen Pilzen. Phytopathol. Z. 90: 64-76.

AnALYTIS S. 1980: Obtaining of sub-models for modeling the entire life cycle of a pathogen. [Über die Erlangung von SubModellen, die zur Beschreibung eines gesamten Lebenszyklus eines Krankheitserregers dienen.] Z. Pflanzenkrank. Pflanzensch. 87: 371-382.

Argyriou L.C., Stavraki H.G. \& Mourikis P.A. 1976: A List of Recorded Entomophagous Insects of Greece. Benaki Phytopathological Institute, Athens, $73 \mathrm{pp}$.

BaBu T.R. \& AzAm K.M. 1988: Biology of Cryptolaemus montrouzieri Mulsant (Coleoptera: Coccinellidae) in relation with temperature. Entomophaga 32: 381-386.

BIRCH L.C. 1948: The intrinsic rate of natural increase of an insect population. J. Anim. Ecol. 17: 15-26.

BodenheIMER F.S. 1951: Citrus Entomology in the Middle East. W. Junk, The Hague, 663 pp.

CAREY J.R. 1993: Applied Demography for Biologists with Special Emphasis on Insects. Oxford University Press, New York, 206 pp.

DeEvey E.S. 1947: Life tables for natural populations of animals. Quart. Rev. Biol. 22: 283-314.

El Hag E.A. \& ZAitoon A.A. 1996: Biological parameters for four coccinellid species in Central Saudi Arabia. Biol. Control 7: $316-319$. 
ENKEGAARD A. 1993: The poinsettia strain of the cotton whitefly, Bemisia tabaci (Homoptera; Aleyrodidae), biological and demographic parameters on poinsettia (Euphorbia pulcherrima) in relation to temperature. Bull. Entomol. Res. 83: $535-546$.

Francardi V. \& Covassi M. 1992: Note bio-ecologishe sul Planococcus novae (Nasonov) dannoso a Juniperus spp. in Toscana (Homoptera: Pseudococcidae). Redia 75: 1-20.

IZHEVSKY S.S. \& ORLINSKY A.D. 1988: Life history of the imported Scymnus (Nephus) reunioni (Col.: Coccinellidae) predator of mealybugs. Entomophaga 33: 101-114.

Jervis M.A. \& Copland M.J.W. 1996: The life cycle. In Jervis M.A. \& Kidd N.A.C. (eds): Insect Natural Enemies. Practical Approaches to their Study and Evaluation. Chapman \& Hall, London, pp. 63-161.

Katsoyannos P. 1996: Integrated Insect Pest Management for Citrus in Northern Mediterranean Countries. Benaki Phytopathological Institute, Athens, $100 \mathrm{pp}$.

Kontodimas D.C. 1997: First record of the predatory insect Nephus bisignatus (Boheman) (Coleoptera: Coccinellidae) in Greece. Ann. Benaki Phytopathol. Inst. 18: 61-63.

Kontodimas D.C. 2004: Study on Ecology of Nephus includens (Kirsch) and Nephus bisignatus (Boheman) (Coleoptera: Coccinellidae) Natural Enemies of Planococcus citri (Risso) (Homoptera: Pseudococcidae). PhD Thesis, Athens, $170 \mathrm{pp}$.

Kontodimas D.C., Eliopoulos P.A., Stathas G.J. \& Economou L.P. 2004: Comparative temperature-dependent development of Nephus includens (Kirsch) and Nephus bisignatus (Boheman) (Coleoptera: Coccinellidae), preying on Planococcus citri (Risso) (Homoptera: Pseudococcidae): Evaluation of a linear and various non-linear models using specific criteria. Envir. Entomol. 33: 1-11.

Liu T.X., Stansly P.A., Hoelmer K.A. \& Osborne L.S. 1997: Life history of Nephaspis oculatus (Coleoptera: Coccinellidae) a predator of Bemisia tabaci (Homoptera: Aleyrodidae). Ann. Entomol. Soc. Am. 90: 776-782.

Longo S. \& BenfatTo D. 1987: Coleotteri entomofagi presenti sugli agrumi in Italia. Informat. Fitopatol. 37: 21-30.

LysyK T.J. 2001: Relationship between temperature and life history parameters of Muscidifurax zaraptor (Hymenoptera: Pteromalidae). Envir. Entomol. 30: 147-156.

Magro A. \& Hemptinne J.L. 1999: The pool of Coccinellids (Coleoptera: Coccinellidae) to control Coccids (Homoptera: Coccoidea) in Portuguese citrus groves. Bol. Sanid. Veget. Plagas 25: 311-320.

Magro A., Araujo J. \& Hemptinne J.L. 1999: Coccinellids (Coleoptera: Coccinellidae) in citrus groves in Portugal: listing and analysis of geographical distribution. Bol. Sanid. Veget. Plagas 25: 335-345.

Messenger P.S. 1964: Use of life tables in a bioclimatic study of an experimental aphid-braconid wasp host-parasite. System. Ecol. 45: 119131.

Persad A. \& Khan A. 2002: Comparison of life table parameters for Maconellicoccus hirsutus, Anagyrus kamali, Cryptolaemus montrouzieri and Scymnus coccivora. BioControl 47: 137-149.

Pinder J.E., Wiener J.G. \& Smith M.H. 1978: The Weibull distribution: a new method of summarizing survivorship data. Ecology 59: 175-179.

Pope R.D. 1973: The species of Scymnus (s.str.), Scymnus (Pullus) and Nephus (Col., Coccinellidae) occurring in the British Isles. Entomol. Mon. Mag. 109: 3-39.

SAS Institute 1989: JMP, A Guide to Statistical and Data Analysis, v. 4.0.2. SAS Institute Inc., Cary, NC.

Southwood T.R.E. 1966: Ecological Methods, with Particular Reference to the Study of Insect Populations. Methuen, London, xvii + $391 \mathrm{pp}$.

SPSS 1999: SPSS 9 for Windows, User's Guide. SPSS Inc. Chicago, IL.

Suzer T., Aytas M. \& Yumruktepe R. 1992: Chemical experiment on citrus white fly (Dialeurodes citri Ashmead), citrus red mite (Panonychus citri Mc. Gregor) and citrus rust mite (Phyllocoptruta oleivora Ashmead) in the Mediterranean region. Zirai Mucadele Arastirma Yilligi (Turkey) no. 22-23, pp. 61-63. [In R.A.E., Series A, 1995-111-2395].

Tingle C.C.D. \& Copland M.J.W. 1989: Progeny production and adult longevity of the mealybug parasitoids Anagyrus pseudococci, Leptomastix dactylopii and Leptomastidea abnormis (Hym.: Encyrtidae) in relation to temperature. Entomophaga 34: 11-120.

Tranfaglia A. \& Viggiani G. 1972: Dati biologici sullo Scymnus includens Kirsch (Coleoptera: Coccinellidae). [Biological data on Scymnus includens Kirsch (Coleoptera: Coccinellidae)] Boll. Lab. Entomol. Agraria "Filippo Silvestri" Portici 30: 9-18.

VigGiani G. 1974: Recherches sur les cochenilles des agrumes. IOBC/WPRS Bull. 3: 117-120.

Wang J.J., Tsai J.H., Zhao Z.M. \& Li L.S. 2000: Development and reproduction of the psocid Liposcelis bostrychophila (Psocoptera: Liposcelididae) as a function of temperature. Ann. Entomol. Soc. Am. 93: 261-270.

Received November 6, 2006; revised and accepted April 2, 2007 